\title{
Development of Tumbler Water Filter Using Ceramic Based As Drinking Water Container in Disaster Area
}

\author{
Sri Yusnita Irda Sari ${ }^{1}$ * \\ ${ }^{1}$ Department of Public Health, Faculty of Medicine, Padjadjaran University, Jl. Prof Eijkman No 38, 40161, Bandung, \\ Indonesia \\ *Corresponding Author. Email: sri.yusnita@unpad.ac.id
}

\begin{abstract}
Access to safety drinking water is one of problems during and after emergency phase in disaster. Disaster victims have higher risk to get water-borned diseases due to lack of safety drinking water as well as poor hygiene and sanitation. Our invention is an appropriate technology which intended to provide humanitarian aid for disaster victims and solve the problem of drinking water supply in inaccessible area without complicated electricity or other energy sources. We modified a simple water treatment system prototype in tumbler size which can transform raw water sources into potable water. This prototype named TELAGA Tumbler, it consists of ceramic water filters which can filter 7,000 liters raw water. Raw water is poured into first container then filtered by ceramic filter which have 0.4 micron pores to relieve microbiological pathogens. Inside the ceramic filter, nano silver is coated as disinfectant agent and fill up with carbon-active to ameliorate the water taste. The prototype in tumbler size might help disaster victim to get drinking water easier without produce more plastic waste. Safe drinking water is urgently needed in fast response to save human life, this innovation might be part of the key to solve the problem in humanitarian aid response.
\end{abstract}

Keywords: disaster, drinking water treatment, innovation, technology

\section{INTRODUCTION}

Access to drinking water and clean water are the most important problem during any disaster since common access to reguler water sources that used to be consumed for drinking water and used for bathing, cooking and other daily activity are outomatically broken or contaminated due to the disaster and most of the water sources are inconsumable. Second problem during and after the disaster is poor hygiene and sanitation condition which is caused mostly due to lack of clean water sources. This condition might increase the risk of pathogen exposure to the disater victims. Many of them are easily infected by dermatitis, respiratory infection, water borne diseases and others that caused by contaminated water sources

Globally, 1.1 billion of peope do not have access to safety water since 2002 and more than 6,500 children died everyday because of diarrhea. ${ }^{1}$ Mortality among children due to diarrhea disease in all over the world were reported 42,000 cases/week; 6,000 cases/day; 4 cases/minute and 1 case in every 14 seconds. $^{2}$ This condition will be worsen if there is disaster happened, the morbidity and mortality due to lack of clean water and safety drinking water will increase significantly. Although the watersources might be available in disaster area, however, raw water sources which are still available in the location might be contaminated and need further treatment to be consumed.

Nowadays, type of humanatarian aids to help the disaster victims particularly to fulfill the need of clean water and safety drinking water is still limited. Mostly the support are given in plastics, either in bottled or glass drinking water that need a certain distribution chain and long transportation to disaster area that not always easily accessible. Beside that, plastic wastes produced from the bottles or glass plastic will cause another problem in disaster area that will cause new problems to overcome to disposing the waste.

In order to overcome the problem of providing safety drinking water to disater victims, an innovation is needed to develop or modify an appropiate technology that can be used to serve standardized drinking water. We modified a simple prototype as water treatment system which can transform raw water sources (e.g. ground water, river, rain and flood water) into potable water. This prototype named TELAGA Tumbler (TELAGA means Teknologi Pelepas Dahaga in Bahasa Indonesia; or Technology of thirstquenching in English). TELAGA is an appropriate technology for disaster period to overcome the problem of providing and delivering drinking water to disaster victims particularly in inaccessible area. TELAGA is developed in tumbler type for individual person so that we do not have to give glass or cup for every people in disaster area. 


\section{METHODS}

This was an experimental study to develop a prototype product and testing the effectiveness in the laboratory. The development of tumbler prototype was conducted by disigning the tumbler using computerized technique by discussion with engineering product designer. The prototype moulding was printed by $3 \mathrm{D}$ printer, then the filtration effectiveness of flow rate time was testing. Water samples before and after filtration by ceramic filter was testing to know the effectiveness of microbiological parameter. Water sample that used as raw water was taken from borehole or groundwater. All the experimental phase was conducted in periode July-August 2019.

Microbiological parameter test using Coliform and E. coli was used to know the effecetiveness in eliminating indicator pathogen. The identification of microbiological parameters was conducted at the Laboratory of Microbiology and Parasitology, Faculty of Medicine, Padjadjaran University. Total Coliforms and E. coli in water samples were examined using the membrane filter method with nitrocellulose membrane filters $(47 \mathrm{~mm}$ in diameter, pore size $0.45 \mu \mathrm{m}$; Merck Millipore) and Chromocult agar (KGaA, Darmstadt, Germany) as the culture medium. The water sample (100 $\mathrm{mL}$ ) was filtered through the membranes and placed on the medium. Media was incubated at $37^{\circ} \mathrm{C}$ for $24 \mathrm{~h}$ until the colonies formed. The sample was reported $E$. coli positive if a purple bluish-colored colony was found. Total coliform bacteria-containing samples were reported if red colonies were found. Total coliform and E. coli bacteria were identified by colony counting expressed in colony-forming units $(\mathrm{CFU}) / 100 \mathrm{~mL}$ water sample. Drinking water is eligible if there are no colonies of total coliforms and E. coli based on the WHO guidelines and the regulations of the Indonesian Health Ministry [24, 25]. The standards of microbiological parameters for drinking water should be nil (zero) for coliforms and E. coli.

TELAGA tumbler consists of 2 containers and 1 ceramic water filters from Nazava tulip Inc. which can filter up to 7,000 liters of raw water and can be utilized for 9 years without replacement of new ceramic filters for individualized user. Raw water is poured into first container, large size particles will be precipitated by gravity in the base of the container, raw water will be filtered by ceramic to second container, the water is flowed by gravity into the third container which then already considered as potable water. Ceramic water filter have 0.4 micron pores to relieve microbiological pathogens like bacteria, cists, parasites etc. Inside the ceramic filter, nano silver is coated in the inner part of ceramic filter which working as disinfectant agent and fill up with carbon-active to ameliorate the taste of the water.

\section{RESULTS AND DISCUSSION}

TELAGA tumbler prototype after printed by $3 \mathrm{D}$ printer showed in figure 1 and the schematic of inside part was illustrated in figure 2 . The first container valume was $650 \mathrm{ml}$ and can be consist maksimal $500 \mathrm{ml}$ of raw water.

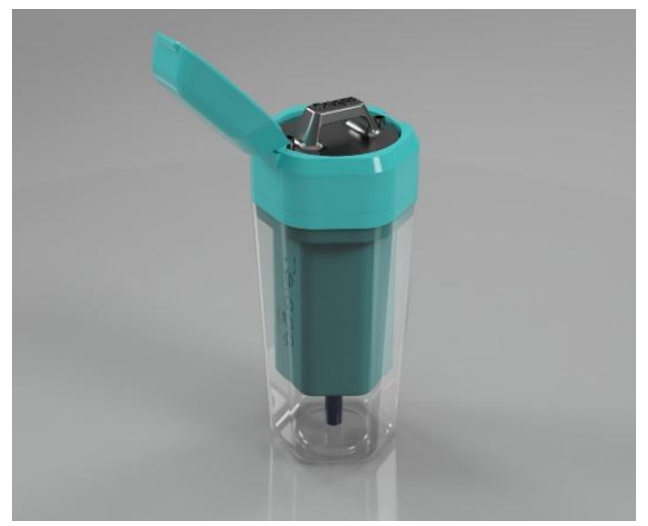

Figure 1. TELAGA Tumbler Moulding by 3D Printer

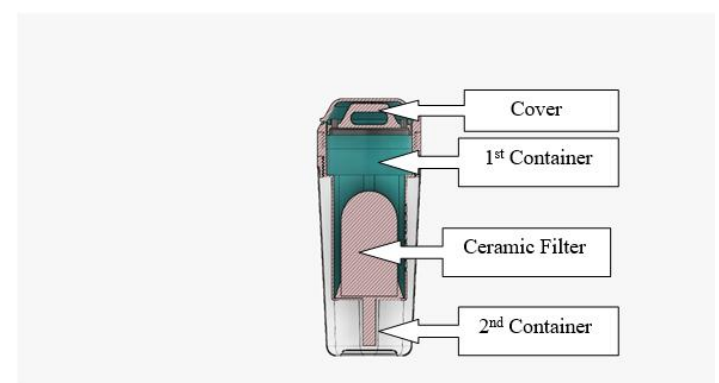

Figure 2. Inside the TELAGA Tumbler

The result of microbiological testing was demonstrated in figure 3. AB 099 was the raw water with numerous number of total Coliform and E.coli colonies, while AM 099 was the water after filtered by ceramic filter. The result of filtered water was found no colony of total Coliform and E.coli that corroborate the result as potable water based on the standard.

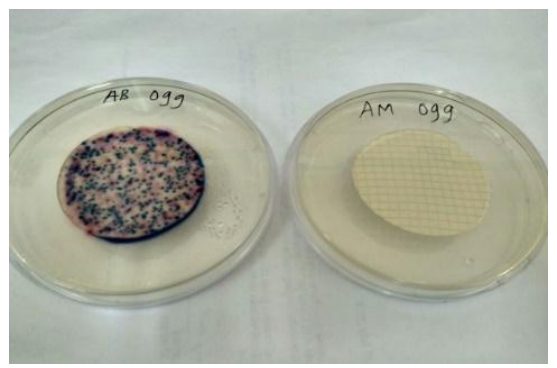

Figure 3. Microbiology Parameter test for Coliform and $E$. Coli of Raw water and Filtration water using ceramic filter

The effectiveness of flow rate was describe in figure 4 . After pouring the raw water to the first container we can start sucking the potable water using the straw after 10 seconds, after 5 minutes the volume of potable water in second container was $100 \mathrm{ml}$ and after 10 minutes the volume was increasing up to $200 \mathrm{ml}$ that was similar to one cup of regular 
mineral water in plastic glass. The maximal filtration will end up at around 30 minutes with about $440 \mathrm{ml}$ of potable water can be filtered by ceramic water, about $60 \mathrm{ml}$ of raw water will be settled at the base of first container.

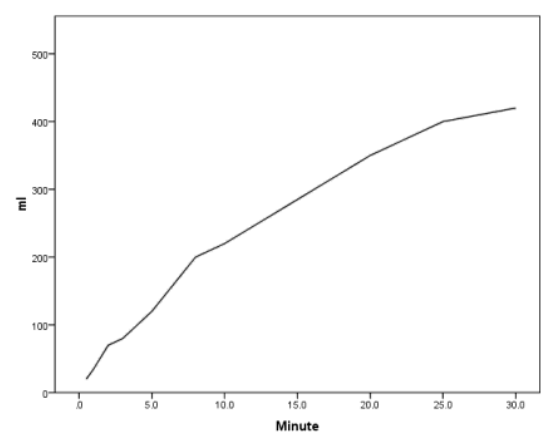

Figure 4. Flow rate of raw water from $1^{\text {st }}$ container to second container
Comparison of some water treatment using water boiling, filtration using TELAGA Tumbler and using mineral water either in gallon container, plastic bottle or plastic glass was describe in table 1 . Some aspects was compared particularly if we want to use it in disaster area, we can find that TELAGA tumbler is more effective and easily use during and after emergency phase of disaster period.

Table 1. Comparison of various method of water treatment

\section{Boiling Water}

\section{Drinking water in Gallon/Bottle/Glass}

\section{TELAGA Tumbler}

\begin{tabular}{|c|c|c|c|}
\hline Advantages & $\begin{array}{l}\text { Effective in eliminate the } \\
\text { pathogen }\end{array}$ & $\begin{array}{l}\text { Practice, ready to drink, } \\
\text { standardized quality }\end{array}$ & $\begin{array}{l}\text { Practice, easy to use with any } \\
\text { type of raw water }\end{array}$ \\
\hline Disadvantages & $\begin{array}{l}\text { 1. Not effective to eliminate } \\
\text { some chemicals and heavy } \\
\text { metals } \\
\text { 2. Need energy source such as } \\
\text { gas or electricity }\end{array}$ & $\begin{array}{l}\text { 1. Need long distribution } \\
\text { system } \\
\text { 2. Producing plastic wastes }\end{array}$ & $\begin{array}{l}\text { Ceramic filter need to be } \\
\text { cleaned up regularly. }\end{array}$ \\
\hline Cost per liter (IDR) & 84 & $\begin{array}{l}894 \text { (Galon) } \\
4,000 \text { (Bottle) } \\
2,000 \text { (Glass) }\end{array}$ & 35 \\
\hline Equipment need & Stove, water container & $\begin{array}{l}\text { Water dispenser or water } \\
\text { pump, glass or plastic cup, } \\
\text { garbage bin }\end{array}$ & Tumbler unit \\
\hline
\end{tabular}

\section{DISCUSSION}

Water treatment technology is already developed in various types, technologies which can produce about 3,000-5,000 liters/hour are commonly complicated, heavy and not easily distributed in disaster area. Mainly, drinking water supply to disaster area is given in bottled water (gallon, bottles or plastic glasses) which need complicated distribution chain and produce new problem due to plastic waste. TELAGA Tumbler was a prototype that developed and disigned to be able to serve drinking water to disaster victims even in remote area and limited resources.

The main filter used in TELAGA tumbler was ceramic filter which can be used to filter raw water in worst condition. This filter have 0.4 micron pores and also containing nano silver that effective to filter and destroy the wall of pathogen cell as shown in figure 3, this microfiltration system is also effectively filterd any kind of large particles and chemicals contamination also effectively absorb by the active carbon inside the filter. The effectiveness of this ceramic filter had been explained in previous articles and already known as one of World Health organization (WHO) recommendation for household water treatment system. ${ }^{3-6}$

The guidelines of drinking water quality standards are referred to the 2010 Ministry of Health regulation number 492 based on physical (smell, color, total dissolved solids, turbidity, taste, and temperature), microbiological (total coliforms and Escherichia coli), chemical (organic, inorganic, pesticides, and disinfectants), and radiological (gross alpha and beta activities) parameters that are in accordance with the World Health Organization (WHO) regulations. ${ }^{7,8}$ However, in this experimental study only microbiological parameter was tested. 
Abdillah, Guido van Hofwegen, and Maulana for all the support and discussion. We also give appreciation to all the staff of the Laboratory of Microbiology and Parasitology, Faculty of Medicine, Padjadjaran University, for accommodating all the processes of this research. This research was funded by ICRS (Indonesian Consortium of Religious Studies) under the Sustainable and Smart Urvan Living Innovation Award 2019. This research was conducted under the Study Centre of Health System in Faculty of Medicine, Padjadjaran University.

\section{REFERENCES}

[1] Shaheed A, Orgill J, Montgomery MA, Jeuland MA, Brown J. Why "improved" water sources are not always safe. Bull World Health Organ. 2014;92(1):283-9.

[2] Bain R, Cronk R, Hossain R, Bonjour S, Onda K, Wright J, dkk. Global assessment of exposure to faecal contamination through drinking water based on a systematic review. Trop Med Int Health 2014;19(8):917-27.

[3] Mellora J, Abebea L, Ehdaiea B, Dillinghamb R, Smitha J. Modeling the Sustainability of a Ceramic Water Filter Intervention. Water Res. 2014;49:286-299.

[4] Wubbels GH, Duran I, Willemse P. Removal efficiency of Silver impregnated Ceramic

filters; A study of the removal of pathogenic bacteria. Waterlaboratorium Noord. 2010

[5] Matthiesa K, Bittera H, Deobalda N, Heinlea M, Diedelb R, Obsta U, et al. Morphology,

composition and performance of a ceramic filter for household water treatment in Indonesia. Water Practice \& Technology. 2015;10(2)

[6] Sari SYI, Alfian AR, Respati T, Agustian D, Raksanagara AS. Comparison of Drinking Water Quality Following Boiling, Household Filtration and Water-Refill in Urban-Slum Area. J Int Dent Med Res. 2019; 12(2): 791-6.

[7] Ministry of Health Republic of Indonesia: Regulation Number 492/MENKES/PER/IV/2010 about Guideline for Drinking Water Quality, 2010. [in Indonesian]

[8] WHO: Rapid Assessment of Drinking Water Quality; A Handbook for Implementation. WHO. Geneva, 2012.
ACKNOWLEDGMENT
The author would like to thank to Widya Latif Indra, Syahri 